Meta

Journal des traducteurs

Translators' Journal

\title{
General Theory of Terminology and Translation Studies
}

\section{Hildegund Bühler}

Volume 27, numéro 4, décembre 1982

URI : https://id.erudit.org/iderudit/002174ar

DOI : https://doi.org/10.7202/002174ar

Aller au sommaire du numéro

Éditeur(s)

Les Presses de l'Université de Montréal

ISSN

0026-0452 (imprimé)

1492-1421 (numérique)

Découvrir la revue

Citer cet article

Bühler, H. (1982). General Theory of Terminology and Translation Studies.

Meta, 27(4), 425-431. https://doi.org/10.7202/002174ar d'utilisation que vous pouvez consulter en ligne.

https://apropos.erudit.org/fr/usagers/politique-dutilisation/ 


\section{GENERAL THEORY OF TERMINOLOGY AND TRANSLATION STUDIES*}

At the 3rd International Congress of Applied Linguistics, Copenhagen, 1972 two pioneering papers were read : one by A. Neubert and one by the late E. Wüster.

In his paper Theorie und Praxis für die Übersetzungswissenschaft (Theory and Practice for Translation Science) (Neubert 1972) Neubert stated that translation studies were then for the first time considered a subject fit for presentation in a plenary session of an AILA (Association Internationale de Linguistique Appliquée) world congress. In the meantime research activities concerned with translating and translation have come to be regarded as a generally accepted branch of applied linguistics (cf. Wilss 1982).

At the aforementioned congress also Eugen Wüster of Austria introduced the General Theory of Terminology as a new interdisciplinary field in his paper Die Allgemeine Terminologielehre. Ein Grenzgebiet zwischen Sprachwissenschaft, Logik, Ontologie, Informatik und den Sachwissenschaften (General Theory of Terminology - a borderline field between linguistics, logic, ontology, information science and the subject fields) (Wüster 1972). At that time Wüster was himself president of the then AILA Commission "Terminology and Lexicography". Wüster's lifelong concern was with questions of terminology or rather special language terminology and its standardization (cf. Wüster 1931/ 1970). Today a Vienna School of Terminology (cf. Felber 1981) based on Wüster's publications and teaching can be marked off from other contemporary developments in the field of Fachsprachenforschung (LSP research), a field where Wüster's pioneering work is now duly acknowledged on an international level.

When Wüster died in 1977, he left an extensive research library at Wieselburg, Lower Austria, where he had entertained a private research centre. This collection of terminological source material was transferred in 1981 to Vienna to the premises of Infoterm, the "International Information Centre for Terminology", which upon Wüster's initiative (cf. Wüster 1974) was established in Vienna in 1971 under a Unesco contract and affiliated to the Austrian Standards Institute. A research project to investigate and make accessible the unfinished

3. CIOMS (1967): Terminologie et lexicographie médicales (UNESCO et OMS), Paris, Masson et Cie.

* Paper read at the $6^{\text {th }}$ International Congress of Applied Linguistics, August 1981, Lund (revised version).

Abstract in : Sigurd, B./J. Svartvik, (eds.), AILA 81, Proceedings I, Lund 1981, 290. 
papers and draft manuscripts in the field of Terminology and related fields left by Wüster was initiated by the author in 1979 under the sponsorship of E. Weis (president of the AILA Commission "Lexicography") in cooperation with Infoterm and a grant was obtained from the Austrian Fonds zur Förderung der wissenschaftlichen Forschung (Austrian Science Research Fund) for Research Project 3938 Erschliess-ung des wissenschaftlichen Nachlasses von E. Wüster (Wieselburg) (Investigation of the Scientific Legacy of E. Wüster). Work was started at Wieselburg in 1980 and continued in Vienna in 1981 in the aforementioned Wüster Research Library at Infoterm, with the author, lecturer at the University of Vienna Institute of Translation and Interpretation, as project supervisor. (For a report on the ongoing project see Bühler 1982a).

Relations between terminology science and the theory and practice of translation had already been envisaged by the late E. Wüster himself. For instance when FIT - the International Federation of Translators - called for the establishment of an "International Committee for the Co-ordination of Terminological Activities", this project was remodeled in cooperation with Wüster (cf. Bühler/Felber 1981). In 1959 Wüster took part in the 3rd World Congress of FIT presenting a paper in which he suggested that concepts and their relationships be investigated and made accessible for reference in systematic dictionaries and vocabularies. Wüster's ideas, which he had previously presented at the International Congress of Linguists in Oslo in 1957, give evidence of an exceptional amount of foresight of subsequent developments in the field of structural semantics (Wüster 1963 and 1959). In 1968 at the Kolloquium on open terminological problems convened at the Auslands- und Dolmetscherinstitut (Institute of Foreign Studies and Interpretation/Translation) of the University of Mainz at Germersheim, Federal Republic of Germany, Wüster gave an opening address outlining the four dimensions of terminology work (Wüster 1969), a lecture which he repeated the same year at the University of Vienna Institute of Translation and Interpretation. In 1974 on the occasion of a symposium on terminology and special lexicography, organized by the Translators Organisation of the Federal Republic of Germany (BdÜ), Wüster, after having been awarded the Goldene Ehrennadel of that organization, spoke on the subject of training in terminology and terminological lexicography (Wüster 1975).

For the future three aspects of the interface between General Theory of Terminology and Translation Studies will have to be given special attention: the didactic, the practical and the theoretical aspects.

Wüster's statements of 1975 were re-examined and supplemented more recently by Sager in his contribution to a commemorative publication for Eugen Wüster (Sager 1979). Since languages for specific purposes (LSP) and terminology as the lexical aspect of LSP play an important part in the work of the translator and interpreter, the teaching of LSP has been accorded a prominent place in the training programs for interpreters and translators on the university level (cf. for instance Petioky 1974, Wilss 1979a, Arntz 1980). More recently they are being complemented by the instruction in terminology work as a supradisciplinary area of study that has received impulses from Wüster's theory (cf. Picht 1979, Arntz 1979a, 1979b, Bühler 1980a). 
The University of Vienna has a long tradition in the teaching of terminology as a science since Wüster himself lectured from 1972 to 1974 at the Institut für Allgemeine und Angewandte Sprachwissenschaft (Institute of General and Applied Linguistics). This lecture series was published in 1979 after Wüster's death as Einführung in die Allgemeine Terminologielehre und terminologische Lexikographie (Introduction to the General Theory of Terminology and Terminological Lexicography) (Wüster 1979) and is now continued by Wüster's former collaborator, the present director of Infoterm.

The Institute of Translation and Interpretation of the University of Vienna follows a LSP-teaching concept geared to the training of fiexible all-round translators and conference interpreters (cf. Petioky 1974). It therefore offers LSP-lecture courses in all the major language sections that follow a 4-semester cycle as well as courses in Rechts- und Wirtschaftssprache (language of law and economics) in several languages. In addition to the aforementioned lecture course on terminology theory, which is also open to students of translation and interpretation, two new courses stressing practical aspects of terminology have been introduced more recently; both are given by the author on the premises of Infoterm. Within the framework of the English section of the Institute of Translation and Interpretation a Terminologieseminar (terminology seminar) is offered, which comprises an introduction to practice-oriented terminology work (i.e. terminography) for translators and interpreters on the basis of the Vienna School of Terminology and requires students to prepare terminological mini-projects (seminar papers) on German and English LSP-terminology in a given field. As part of the general basic training for translators and interpreters another seminar course called Konversatorium zur Terminologieforschung (terminology research) is given, offering an introduction to terminology theory geared especially to translators, consultation in regard to independent terminological projects such as diploma theses, as well as user education for the Wüster Research Library at Infoterm.

These two courses were preceded during the fall term of 1979 by a pilot project of the author "General Theory of Terminology and its Practical Applications. A University Course for Translators" at the Division of Interpretation and Translation of the School of Languages and Linguistics of Georgetown University, Washington D.C. (for a course outline of this one-semester course see Bühler 1980 a). The course was given in two main parts (theoretical background, practical applications) of five two-hour sessions each. Since in a course on terminology geared to translators the approach to the theory of terminology will have to be essentially user-oriented, an attempt was made in part $I$ to reduce General Theory of Terminology to the basic facts in two two-hour sessions. In addition, a "Popular English Introduction to General Theory of Terminology" was recorded in a studio session on a 30-minute videocassette intended for future use at the university. It can also be understood as a pilot project for low-level basic training in terminology for students with varied backgrounds that may not always have included formal training in Western conceptual thinking and with a non-native command of English. The discussion of practical applications in part II of the course was designed to prepare future 
translators for their presumptive tasks of terminographer and terminology user (cf. Sager 1979:153). Several students were assigned the task of preparing short LSP-glossaries in carefully limited subject fields in their non-IndoEuropean mother tongues, work that could not have been successfully completed without a theoretical basis. Most of the time was however devoted to an introduction to the possibilities and problem areas of terminological data banks used as a translation aid. As has been pointed out elsewhere, it is to be expected that such instruction during the early stages of training will reduce user reluctance on the part of translators as well as shorten on-the-job training periods (Bühler 1980b).

It is suggested that a one-semester basic course on general theory of terminology and its practical applications be envisaged as a compulsory part of a futureoriented training program for translators on the university level, and further models for such a course are called for.

The user-oriented approach to Wüster's General Theory of Terminology should be discussed in the context of computer-aided terminological lexicography, since in our time translators will be increasingly required to make use of terminological data banks.

Wüster himself prepared an interlingual model dictionary based on his theories in a technical field (Wüster 1968), but did not live to witness the full development of computer-aided terminological lexicography and no reference to it was made in his lecture course. However, in an unpublished manuscript he mentions the fact that he as an Austrian was guest of honor in 1969 at the foundation ceremony for the Bundessprachenamt (Federal Office of Languages) at Hürth, Federal Republic of Germany (Wüster 1971). This institution was the first in Europe to operate a terminological data bank used as a translation aid.

No attempt shall be made to enumerate or evaluate the various systems of such banks in operation or in the planning stage. But attention should be drawn to the fact that during the "Meeting of Experts on Terminological Data Elements" convened in Vienna in September 1980 (Infoterm 1980) it became obvious that, since terminological records are user-dependent, term banks that are used for translation purposes and have to supply foreign language equivalents have problems distinct from other types of banks. Thus, for instance, the question of synonymy has different aspects for translators than for information scientists, phraseological entries present specific problems, quality criteria must be considered essential. The minimum set of data elements required for translation purposes has yet to be determined and such a limited list is to be considered a prerequisite for international cooperation.

It will therefore be a worthwhile subject for applied translation studies to investigate the scope and structure of terminological data elements for translation-aid term banks in the light of the principles of terminological lexicography based on Wüster.

As to the third aspect, the theoretical interface, an attempt will have to be made to relate the terminology science of Wüster to the theory of translating and translation and to describe its place in such a theory. Since both fields can be said to be still in the stage of formation, very few attempts have been made to that end (cf. Picht 1975, Wilss 1979b). 
The basic notion in Wüster's lifelong concern with the phenomenon of language is what he used to call bewußte Sprachgestaltung (deliberate shaping of the language). According to his monumental Systematic Defining Dictionary of the basic concepts of the theory of terminology (cf. Bühler $1982 \mathrm{~b}$ ), which he left unfinished on his desk, language planning is one aspect of the above. In an unfinished draft manuscript, which was translated into English and published after his death, he holds that language planning is characterized by two distinct and independent processes : the linguistic aspect, the deliberate creation of language items, and the sociological aspect, the deliberate adoption of these language items, especially standardization (Wüster 1980).

Language items in the sense of Wüster are lexical units. In their study on "Standardization of Terminology in a Model of Communication" Johnson and Sager make a distinction between words, terms, and standards, with "reference" (which relates the conceptual to the lexical plane) as the distinguishing criterion. Words are lexical items characterized by general reference, where the referential properties are vague or generalized and not specific to any discipline. Terms are items characterized by special reference within a discipline. If agreement can be achieved on the part of all users to use a term with a specified fixed reference, that term is recommended as a standard (Johnson/Sager 1980).

According to Wüster, terminology work starts with the systematization of concepts to which terms are assigned later, either by selection from existing terms or by creating new ones. This assignment is a deliberate and permanent one (Wüster 1979). Thus Felber, a disciple of Wüster, in a recent study differentiates between three types of linguistic signs: Wort, Fachausdruck, and Thesauruswort. He holds that a Wort (common language word) is kontextabhängig (context dependent), while a Fachausdruck (term or standard belonging to a special language) depends upon the concept system to which it belongs (begriffssystemabhängig). According to Felber a Fachausdruck is permanently assigned to a concept by some authority, be it a terminology commission or an expert in the field (Felber 1980).

From the statements of Johnson/Sager and Felber we may conclude that the borderline between term and standard runs along the linguistic-sociological line set out by Wüster, and that normative processes are characteristic of languages for specific purposes.

Furthermore Johnson and Sager hold that "terms can only be used as such if the user already possesses the configuration of language which determines the role of the term in a structural system" (Johnson/Sager 1980:87). Felber goes one step further by claiming that a Fachausdruck will retain its meaning, delimited by its place in a concept system, also in the actual context of a specific subject field (Fachkontext) (Felber 1980).

How do the above assertions relate to the theory of translation? It seems evident that Wüster's theory must be discussed within the framework of texttype-oriented theories of translation (cf. e.g. Broeck 1980). The phenomenon of what the author would like to call context-free fixed reference, attained by some form of consensus within a specific user group, will be essential for 
those sorts of texts where it is necessary to make communication maximally effective (cf. also Bühler 1979).

Translation research with a textual and communicative orientation might therefore pay greater attention to the tendency in specified types of texts to replace the natural creativity of language by normative processes as well as to the normative function of translation itself in such processes. Since standardization represents a transition from the parole level to the langue level, it will also be necessary to re-examine the status of translation theory as a linguistique de la parole (Sprachverwendungslinguistik) in the light of the above.

Hildegund Bühler

\section{REFERENCES}

ARNTZ, R., (1979a): "Aufbau einer terminologiewissenschaftlichen Lehrveranstaltung im Rahmen der Übersetzer- und Dolmetscherausbildung', in Fachsprache, vol. 1, $\mathrm{n}^{\circ}$ 1-2, p. 43-50.

ARNTZ, R., (1979b) : "Dic Studienkomponente Terminologielehre in der Ausbildung von Übersetzern und Dolmetschern", in Lebende Sprachen, XXIV. Jahrgang, Heft 1, p. 1-3.

ARNTZ, R., (1980): "Modelle und Methoden der fachsprachlichen Übersetzerausbildung, in C. Gnutzmann/J. Turner (eds.), Fachsprachen und ihre Anwendung, Tübingen, p. 95-119.

ARNTZ, R., (1981): "Terminology as a Discipline in the Training of Translators and Interpreters in Languages for Special Purposes, in Infoterm Series 6, Theoretical and Methodological Problems of Terminology, München, p. 524-529.

BROECK, R. van den, (1980): "Toward a Text-Type-Oriented Theory of Translation", in S.O. Poulsen/W. Wilss (eds.), Angewandte Übersetzungswissenschaft, Referate anläßlich des Internationalen Übersetzungswissenschaftlichen Kolloquiums an der Wirtschaftsuniversität Arhus/Dänemark, p. 19-21, Juni, Arhus/Dänemark.

BÜHLER, H., (1979): "Suprasentential Semantics and Translation", in Meta, vol. 24, ${ }^{\circ} 4$, p. $451-458$.

BÜHLER, H., (1980a): "General Theory of Terminology and its Practical Applications. A University Course for Translators", in Fachsprache, vol. 2, n², p. 50-54.

BÜHLER, H., (1980b) : "MAT and User Reluctance", in TermNetNews 1-1980, p. 63-65.

BÜHLER, H., (1982a): "The Scientific Legacy of Eugen Wüster (1898-1977)", in Infoterm Series 7, Terminologies for the Eighties, with a special section: 10 Years of Infoterm, München, p. 96-116.

BÜHLER, H., (1982b): "Grundbegriffe der Allgemeinen Terminologielehre. Aus dem Nachlaß von Eugen Wüster" , in Muttersprache, 5-6/82, forthcoming.

BÜHLER, H. and H., FELBER, (1981): "TermNet Aids Translators" in Proceedings of the IX World Congress of the International Federation of Translators (FIT), Warsaw, forthcoming.

FELBER, H., (1980): "Einige Grundfragen der Terminologie", in Terminologie, Bulletin $\mathrm{n}^{\circ} 36$, CCE, Service de Traduction, Bureau de Terminologie, Luxembourg, p. 7-37.

FELBER, H., (1981): "The Vienna School of Terminology. Fundamentals and its Theory", in Infoterm Series 6, Theoretical and Methodological Problems of Terminology, München, p. 69-86.

INFOTERM, (1980), Report on the Meeting of Experts on Terminological Data Elements, 29. (TermNet 4-80).

JOHNSON, R.L. and J.C. SAGER, (1980): "Standardization of Terminology in a Model of Communication', in SAGER J.S. and J.A. FISHMAN (eds.), International Journal of the Sociology of Language 23, The Hague, p. 81-104.

NEUBERT, A., (1972): "Theorie und Praxis für die Übersetzungswissenschaft", in Proceedings, Vol. III, $3^{\text {rd }}$ Congress of Applied Linguistics, Copenhagen, p. 482-490.

PETIOKY, V., (1974): "Fachsprachen in der Ausbildung der Übersetzer und Dolmetscher'" in KaPP V. (ed.), Übersetzer und Dolmetscher, Heidelberg, p. 109-122.

PICHT, H., (1975): Verbindungslinien zwischen der terminologischen Forschung und anderen Forschungsdisziplinen, unpublished typescript, Wüster Library, Infoterm.

PICHT, H., (1979): "Der Terminologieunterricht an der Handelshochschule Kopenhagen" in CEBAL Special Issue on Terminology, Publication $n^{\circ} 5$, Copenhagen, p. 28-82.

SAGER, J.C., (1979): "Training in Terminology : Needs, Achievements, and Prospectives in the World", in Felber H., F. LANG and G. Wersig (eds.), Gedenkschrift für Univ.-Prof. Dr. Eugen Wüster, München, p. 149-163. 
WILSS, W., (1979a): "Probleme und Perspektiven der Studiengänge Übersetzen und Dolmetschen and der Universität des Saarlandes", in Lebende Sprachen, 4/1979, p. 147-150.

WILSS, W., (1979b): "Fachsprache und Übersetzen" in FELBER H., F. LANG and G. WerSIG (eds.), Gedenkschrift für Univ.-Prof. Dr. Eugen Wüster, München, p. 177-195.

WILSS, W., (1982): The Science of Translation. Problems and Methods, Tübingen.

WUUSTER, E., (1931/1970) : Internationale Sprachnormung in der Technik, (3rd ed. 1970), Bonn.

WUUSTER, E., (1963): "Die Struktur der sprachlichen Begriffswelt und ihre Darstellung in Wörterbüchern," in Proceedings of the $3^{\text {rd }}$ Congress of FIT, Oxford, p. 415-443. See also WÜSTER, E., (1959): "Die Struktur der sprachlichen Begriffswelt und ihre Darstellung in Wörterbüchern" in Studium Generale 12, p. 615-627.

WUSTER, E., (1968): The Machine Tool, London.

WÜSTER, E., (1969): "Die vier Dimensionen der Terminologiearbeit" in Mitteilungsblatt für Übersetzer und Dolmetscher, 2/1969, p. 1-6, 5/1969, p. 1-5.

WÜSTER, E., (1971) : Die Bedeutung des Internationalen Informationszentrums für Terminologie, unpublished ms., Wüster Library, Infoterm, W 574.

WÜSTER, E., (1972): "Die allgemeine Terminologielehre - Ein Grenzgebiet zwischen Sprachwissenschaft, Logik, Ontologie, Informatik und den Sachwissenschaften", in Proceedings, vol. III, $3^{\text {rd }}$ Congress of Applied Linguistics, Copenhagen, p. 640-655.

WUUSTER, E., (1974) : The Road to Infoterm. Infoterm Series 1, München.

WÜSTER, E., (1975): "Die Ausbildung in Terminologie und terminologischer Lexikographie" in Lebende Sprachen, 2/1975, p. 33-37.

WÜSTER, E., (1979): (Bauer, L., ed.), Einführung in die Allgemeine Terminologielehre und Terminologische Lexikographie, Wien-New York.

WÜSTER, E., (1980) : "Introduction (Fragment of a Draft)", in SAGER J.S. and J.A. Fishman (eds.), International Journal of the Sociology of Language 23, The Hague, p. 15. 